\title{
Analisis Kontrastif Kalau dalam Bahasa Indonesia dengan To, Ba, Tara dalam Bahasa Jepang
}

\author{
THAM ITA ISLAMI INDRASWARI \\ U niversitas M uhammadiyah Yogyakarta; Jl. L ingkarselatan Tamantirto K asihan \\ Bantul D aerah Istimewa Yogyakarta 55183 \\ thamita.indra@umy.ac.id; +628562400 0371
}

\begin{abstract}
ABST RAK
Pada Bahasa Jepang maupun Bahasa Indonesia, dijumpai jenis kalimat luas bertingkat yang menyatakan syarat. Pada Bahasa Indonesia, jenis kalimat ini ditandai oleh penggunaan konjungsi kalau dalam kalimat. Sedangkan pada Bahasa Jepang, kalimat yang menyatakan syarat diwujudkan dengan penggunaan partikel to, ba, dan tara. Artikel ini berisi tentang deskripsi persamaan dan perbedaan to, ba, tara dalam Bahasa Jepang dan kalau dalam Bahasa Indonesia. Fokus pembahasan persamaan dan perbedaan diarahkan pada segi makna, kategori predikat, dan modus kalimat. Kalau dalam Bahasa Indonesia memiliki tujuh kategori makna. To memiliki tujuh kategori makna, ba empat kategori makna, dan tara tiga kategori makna. Sehingga, kalau dalam bahasa Indonesia menjadi divergen ketika diterjemahkan dalam bahasa Jepang. Ada lima makna dari kalau yang bisa dipadankan langsung dengan to, sedangkan dua makna lain lebih tepat dipadankan dengan ba atau tara. Untuk memilih padanan yang tepat, hal yang perlu diperhatikan adalah makna serta modus kalimat dari bahasa Indonesia dan bahasa Jepang; khususnya makna serta modus yang menunjukkan gejala shinki, ketsujo dan bunretsu. Dari segi kategori predikat dalam kalimat, baik bahasa Jepang maupun bahasa Indonesia menunjukkan karakteristik yang berpadanan. Tetapi, dari segi modus kalimat, khusus untuk ba, saat modus menyatakan imperatif, permohonan, saran, ajakan atau kalimat yang menyatakan maksud predikat tidak bisa berupa verba; kecuali jika subjek dalam klausa I dan klausa II berbeda. Juga, diperbolehkan jika predikat dalam klausa I menjelaskan kondisi dari topik klausa.

Kata kunci: analisis kontrastif, to, ba, tara, kalau
\end{abstract}

\section{ABSTRACT}

Complex sentences as a type of linguistic unit, can be found in any language. Complex sentence can represent particular meaning, purpose, or function. In Japanese language, the use of particles to, ba, tara in complex sentence represent the meaning of terms or conditions. Meanwhile, in Indonesian language conjuction of kalau is commonly used to represent terms or conditions. This articles serve to describe the difference and similarity between to, ba, tara in Japanese Language in contrast to kalau in Indonesian Language. Description between the two language will be focused in categories of sentence meaning, the stucture of predicate used in sentence, and the mode of sentence. Kalau in Indonesian Language has seven categories of meaning. In contrast, To have seven cat- 
egories of meaning, ba four categories of meaning, and tara has three categories of meaning. Thus, kalau in the Indonesian language becomes divergent when translated to Japanese language. There are five meanings from kalau that can be paired directly with to, while two other meanings will be appropiate if paired with ba or tara. This fact shows that between the two languages, in terms of complex sentence which express terms and conditions while similarity are found, divergent and convergent phenomenon of language also found . In terms of predicate used in sentence, both Japanese and Indonesian languages show similar characteristics. However, in terms of the sentence mode, especially for ba, when the mode states imperatives, requests, suggestions, invitations or stating purpose, the predicate can not be a verb; unless the subject in first clause and second clause is different. Also, it is permissible if the predicate in first clause describes the condition of the clause topic.

Keyword: contrastive analysis, to, ba, tara, kalau

\section{PENDAHULUAN}

Pada sistem gramatika bahasa Jepang dan bahasa Indonesia, sama-sama dikenal jen is kal imat luas bertingkat yang menyatakan syarat; dalam bahasa Jepang dinyatakan oleh penggunaan to, ba, tara (Iori, dkk 2000: 220-227) sedangkan dalam bahasa Indonesia dinyatakan oleh penggunaan kalau, jika, bila, apabila, asal (Chaer, 2009: 98-99).

Penerjemahan to, ba, tara sering menjadi masalah bagi pembelajar bahasa Jepang yang bukan penutur asli. Partikel to, ba, tara memiliki aturan tersen diri dalam pemakaiannya. Pada beberapa kondisi tertentu keempatnya tidak bisa saling bersubtitusi, berbeda dengan penggunaan kalau, jika, bila, apabila, asal dalam bahasa Indonesia yang bisa saling bersubtitusi. Sayangnya, dalam bahasa Indonesia keempatnya umum diterjemahkan menjadi satu kata saja, yaitu "kalau"; seperti yang tampak pada contoh berikut:

(1) このボタンを押す上、お釣りが出ます。

K ono botan o osu to, otsuri ga demasu.

Kalau tombol ini ditekan, uang kembalian akan keluar.

(MNTK I, 2000: 148)

(2) お金があったら、旅行します。

0 kane ga attara, ryokoushimasu.

Kalau punya uang, akan pergi berwisata.

(MNTK I, 2000: 160) 
（3）彼が行けば、わたしも行きます。

$\mathrm{K}$ are ga ikeba, watashi mo ikimasu.

Kalau dia pergi, saya juga pergi.

(M NTK II, 2001: 62)

Pada penelitian yang dilakukan oleh Fahmi (2006) diuraikan tentang kesalahan penggunaan kalimat bersyarat ba, tara, nara, dan to yang dilakukan oleh mahasiswa perguruan tinggi di Indonesia, yang mempelajari Bahasa Jepang. Pada pen elitian ini, diperoleh hasil tiga jenis kesalahan yang sering dilakukan mahasiswa, yaitu:

1. kesalahan penggunaan partikel (joshi no ayamari), contoh: otona ni nareba sensei ni naritai desu (2006:51); kalimat ini harusnya berbunyi otona ni nattara sensei ni naritai desu

2. kesalahan men gubah bentuk kata kerja yan g ditempeli ba, tara, atau nara (joukenbun no tsukurikata no ayamari), contoh:

gohan o tabekereba teo awanakereba narimasen (2006:53), kalimat ini harusnya berbunyi gohan 0 tabereba te 0 awanakereba narimasen

3. kesalahan pada kalimat Ianjutan setelah partikel (joushi); kesal ahan berada pada tatar sintaksis, makna, dan pemakaian (bunsho no tsukurikata no ayamari); contoh:

ame ga futtara kono kasa o motte kudasai (2006:55), harusnya kalimat akhir berupa kalimat seperti soto de asobanaide kudasai Kesalahan berbahasa yang terjadi diakibatkan oleh over generaliazation dalam penerjemahan to, ba, tara, nara menjadi kalau seperti yang tampak pada contoh kalimat (1), (2), dan (3). Karena padanan dalam bahasa Indonesianya sekilas tampak sama, pembelajar cenderung berpikir bahwa aturan penggunaannya pun menjadi sama. Karena itu, artikel ini ditujukan sebagai langkah lanjutan untuk mengantisipasi kesalahan berbahasa poin 1 dan 3, sehingga pembelajar lebih awas terhadap poin-poin yang perlu diperhatikan ketika menerjemahkan dan membuat kalimat yang menggunakan to, ba, tara dalam Bahasa Jepang maupun kalau dalam Bahasa Indonesia. Pada artikel ini, pembahasan 
difokuskan pada persamaan dan perbedaan to, ba, tara dalam bahasa Jepang dengan kalau dalam bahasa Indonesia dari segi makna, kategori predikat, dan modus kalimat

\section{PEMBAHASAN}

Pada bagian ini, akan diuraikan pengertian kalimat luas bertingkat, hubungan antar klausa, tolak ukur dalam analisis kontrastif, serta pembahasan mengenai persamaan dan perbedaan to, ba, tara dalam Bahasa Jepang dengan kalau dalam Bahasa Indonesia.

\section{PENGERTIAN KALIMAT LUASBERTINGKAT}

Chaer (2009: 45-46) menguraikan bahwajeniskalimat dalam bahasa Indonesia bisa dibedakan berdasarkan:

a. kriteria unsur predikatnya: verbal, ajektifal, nominal, preposisional, numeral, dan adverbial

b. kriteria jumlah klausa: sederhana, bersisipan, majemuk rapatan, majemuk setara, majemuk bertingkat, majemuk kompleks

c. kriteria modusnya deklaratif, interogatif, imperatif, interjektif, optatif.

Jenis kalimat dalam bahasa Jepang pun tidak jauh berbeda dengan jenisyang ditemukan dalam bahasa Indonesia, Iori (2000: 154) membagi kalimat menjadi tiga jenis berdasarkan:

a. jumlah klausa yang membangun kalimat: kalimat sederhana (tanbun) atau kalimat majemuk (fukubun)

b. kelas kata yang menempati posisi predikat dalam kalimat: kalimat verbal (doushibun), kalimat ajektival (keiyoushibun), kalimat nominal (meishibun)

c. fungsi ungkapan (hyougen kinou): meireibun (kalimat imperatif), iraibun (kalimat permohonan), kanyuubun (kalimat ajakan), ishibun (kalimat yang menyatakan maksud), ganboubun (kalimat yang menyatakan harapan), heijoubun (kalimat deklaratif), gimonbun (kalimat tanya).

Kalimat luas dalam tata bahasa tradisional disebut dengan kalimat majemuk bertingkat atau kalimat majemuk subordinatif, 
sepadan dengan fukubun dalam bahasa Jepang. Chaer (2009) menggunakan istilah kalimat luas bertingkat untuk merujuk kalimat majemuk bertingkat.

Penggunaan istilah kalimat luas merujuk pada isi kalimat yang mengandung lebih banyak informasi. Pada kalimat luas tercantum fungsi keterangan lebih dari satu, seperti keterangan tambahan pada objek, subjek, atau fungsi lainnya. Pada kalimat luas juga dapat ditemui keterangan aposisi, sisipan klausa, penyatuan fungsi yang sama dari dua klausa atau lebih, gabungan klausa berkedudukan setara atau setingkat, gabungan klausa berkedudukan tidak setara, serta gabungan tiga klausa atau lebih yang berhubungan secara koordinatif atau subordinatif.

Penggunaan istilah kalimat bertingkat merujuk pada kedudukan klausa yang ada pada kalimat, dimana klausa yang ada pada kalimat memiliki kedudukan yang tidak sama. Klausa utama berupa klausa bebas, sedangkan klausa bawahan merupakan klausa terikat.

Pada artikel ini, istilah jenis kalimat menurut fungsi ungkapan dalam bahasa Jepang dipadankan dengan istilah kategori kalimat berdasarkan modus, karena dalam bahasa Indonesia keduanya merujuk pada konsep yang sama.

\section{HU BU NGAN ANTAR KLAU SA}

Kalimat luas bertingkat memiliki hubungan semantis antar klausa pembangunnya. Chaer (2009: 179) menyatakan bahwa penggabungan klausa secara bertingkat dapat memberi makna sebab -akibat, syarat, tujuan, waktu, kesungguhan, perkecualian, atau perbandingan. Hubungan tersebut ditunjukkan lewat pemakaian konjungsi dalam kalimat. Kalimat luas bertingkat yang menyatakan syarat ditunjukkan dengan pemakaian konjungsi persyaratan kalau, bila, apabila, bilamana, jikalau, dan asal. Selain itu, dijumpai pula konjungsi persyaratan yang berupa pengandaian yang ditunjukkan oleh pemakaian kata andaikata, seandainya, dan andaikan.

Konjugsi kalau digunakan untuk menyatakan 'syarat', dapat 
diletakkan di awal kalimat atau di tengah kalimat. Konjungsi kalau dapat disubstitusi dengan jika maupun jikalau. Tetapi, konjungsi jikalau lebih menunjukkan penekanan dibandingkan konjungsi jika (Chaer, 2009:99). Konjungsi bila juga dapat digunakan untuk menyatakan 'syarat', dapat digunakan untuk menggantikan konjungsi kalau; serta dapat disubstitusi dengan bila, a pabila. Secara semantik konjungsi bilamana dan apabila lebih menegaskan dibanding konjungsi bila. Konjungsi asal sama dengan kalau dan bila, tetapi lebih lazim digunakan dalam ragam nonformal.

Konjungsi dalam bahasa Jepang bisa dipadankan dengan istilah setsuzokushi; tetapi to, ba, tara termasuk dalam kelas kata partikel (joshi) bukan setsuzokushi (C hino, 2004). M eskipun begitu, to, ba, tara merupakan bagian dari juuzokusetsu (klausa subordinatif) yang digunakan untuk menyatakan persyaratan (jouken 0 arawasu juuzokusetsu).

\section{ANALISISKONTRASTIF}

Analisis kontrastif dikenal pula dengan istilah linguistik kontrastif, dalam bahasa Jepang disebut dengan istilah taishou gengogaku. C abang ilmu ini men gkaji perbedaan dan persamaan struktur juga aspek lain yang terdapat dalam dua bahasa atau lebih. A spek yang menjadi kajian analisis kontrastif antara lain: fonetik, fonologi, morfologi, sintaksis, semantik, bahkan meluas hingga pragmatik dan perilaku non-linguistik yang mendasari ucapan dalam bahasa tertentu.

Pada perkembangannya, analisis kontrastif menjurus ke dua arah, pertama analisis kontrastif yang bersifat kegiatan deskripsi persamaan dan perbedaan saja; kedua analisis kontrastif yang menekankan pada latar belakang dan kecenderungan timbulnya perbedaan serta persamaan di antara bahasa yang diteliti.

Pada artikel ini aspek yang menjadi kajian adalah sintaksis, dimana analisis dilakukan untuk mencari deskripsi persamaan serta perbedaan to, ba, tara dalam Bahasa Jepang dengan kalau dalam Bahasa Indonesia, dilihat dari segi makna kalimat, kategori 
predikat, serta modus pada kalimat yang mengandung to, ba, tara, serta kalau. Tolak ukur yang dapat dipakai dalam analisis adalah sebagai berikut (Koyanagi, 2006: 53 dalam Sutedi, 2009: 131):

a. Aspek bahasa tersebut dijumpai dalam kedua bahasa dan berpadanan (icchi)

b. Aspek bahasa tersebut dijumpai dalam bahasa I tetapi tidak ada padanannya dalam bahasa II (ketsujo)

c. Aspek bahasa tersebut tidak dijumpai bahasa I tetapi ada dalam bahasa II (shinki)

d. A spek bahasa tersebut divergen antara bahasa I dan bahasa II (bunretsu)

e. Aspek bahasa tersebut konvergen antara bahasa I dan bahasa II (yuugou)

Pada artikel ini, metode yang digunakan adalah analisis kontrastif deskriptif, dengan membuat deskripsi dari masingmasing unsur bahasa, kemudian mengkontraskan antara unsur yang ada pada bahasa I dan bahasa II. Bahasa yang menjadi bahasa I adalah bahasa Indonesia (kalau), sedangkan bahasa II adalah bahasa Jepang (to, ba, tara). D ata yang digunakan untuk analisis pada artikel ini dikumpulkan dari buku teks pelajaran Bahasa Jepang dan Bahasa Indonesia, kamus gramatika, serta sumber lainnya. Data kalimat yang dikumpulkan berupa data kalimat jitsurei, dengan total data yang terkumpul sebanyak 69 kalimat. Langkah-langkah penelitian yang dilakukan adalah sebagai berikut:

a. Pengumpulan data kalimat berbahasa Jepang dan berbahasa Indonesia

b. Pembuatan uraian karakter data dalam bentuk deskripsi makna, deskripsi unsur pembentuk predikat, dan deskripsi modus kalimat untuk data berbahasa Jepang dan berbahasa Indonesia

c. Kategorisasi data kalimat berdasarkan: makna, predikat kalimat, serta modus kalimat

d. Pemberian kode untuk setiap jenis makna, predikat, modus 
kalimat; sebagai penanda untuk perbandingan antara bahasa I dan bahasa II

e. Pencarian persamaan dan perbedaan melalui tolak ukur kontrastif seperti yang diusulkan oleh Koyanagi, 2006: 53 dalam Sutedi, 2009: 131

f. Penarikan simpulan dari hasil analisis

\section{PARTIKEL TO, BA, TARA DALAM BAHASA JEPANG}

Pada bagian ini akan diuraikan mengenai makna, kategori predikat serta modus kalimat yang men gandung partikel to, ba, dan tara..

a. Struktur dan Makna To, Ba, Tara

1) Makna, Kategori Predikat, dan Modus Kalimat To

Partikel to dapat digunakan untuk membentuk kalimat majemuk yang menyatakan pengandaian. Jika muncul pada kalimat dengan kala non-lampau, menyatakan makna:

a) Aktifitas/ hal yangmuncul pada klausa II terjadi segera setelah hal pada klausa I terjadi.

Contoh:

(5) メールを出すと、すぐ返事が来る。

b) Menunjukkan hubungan persyaratan bahwa jika klausa I terjadi, maka secara otomatis klausa II akan terjadi Contoh:

(6) このボタンを押すと、カーテンが閉まります

c) M enunjukkan suatu kebiasaan (shuukan) atau suatu hal yang terjadi berulang; yang kini masih berlangsung

Contoh:

(7) 天気がいいと、毎朝ジョギングに行く。

(8) 彼は打金があると、パチンコに行く

d) Menunjukkan suatu kondisi yang umum terjadi (ippanteki), suatu konsekuensi (kekka) yang umum terjadi

Contoh:

(9) 1 と2を足すと、3 亿なる。

(10) 日本では春になると、桜がさきます。

Jika to muncul dalam kalimat dengan kala lampau, to 
menunjukkan makna:

e) Menunjukkan makna 'penemuan' (discovery); atas 'usaha' (hataraki) yang dilakukan pada klausa I, maka 'hasil' (kekka) pada klausa II ditemukan.

Contoh:

（11）ドアを開けると、小さな子どもがドアの前に立っていた。

(12) 四つ角を曲がると、寸ぐ彼のマンションが見えた。

f) Menunjukkan serangkaian aksi yang berhubungan dengan subjek yang menjadi topik pembicaraan

Contoh:

(13) 男は部屋に入ると、友達に電話をした。

g) Menunjukkan makna suatu kebiasaan yang pernah berlangsung.

Contoh:

(14) 彼は酒を飲むと、暴力を振るった。

Partikel to yang menyatakan hubungan persyaratan dapat digunakan dalam kalimat verbal, kalimat ajektival, dan kalimat nominal, seperti yang nampak pada contoh berikut:

(15）それは先生に聞くとすぐ分かった。(verbal)

(16) タイヤは古いとあぶないですよ。(ajektival)

(17) 魚がきらいだと日本へ行ったとき困りますか。(ajektival)

(18) 学生だと割引があります。(nominal)

Partikel to tidak dapat digunakan dalam kalimat imperatif, kalimat permohonan, kalimat yang menyatakan saran, kalimat yang menyatakan ajakan atau kalimat yang menyatakan maksud. Simak contoh berikut:

(19)？ 仕事が早く終わると私のうちに来たらどうですか。

(20)? 仕事が早く終わると私のうちに来ませんか。

(21)? 桜が咲くと、花見に行くつもりだ。

(22)? 食事ができると、呼んでください。

Partikel to dapat digunakan baik dalam bahasa lisan maupun bahasa tulisan. Subjek pada kalimat yang men ggunakan partikel to diikuti oleh partikel ga. 
2) Makna, Kategori Predikat, dan Modus Kalimat Ba

Partikel ba dapat digunakan untuk membentuk kalimat majemuk yang menyatakan persyaratan; kalimat-kalimat tersebut dapat muncul dalam kala lampau dan non-lampau. Kalimat majemuk yang menggunakan partikel ba dalam kala non-lampau menyatakan makna berikut:

a) M enyatakan suatu kondisi yang umum (ippanteki)Oterjadi, suatu kondisi yang bersifat logis (ronri), kondisi yang menyatakan sebuah sebab/ alasan

(23) 春が来れば、花が咲く。

(24）品がよくて安ければ、よく売れます。

(25) 話せば、わかる

（26）試験に合格すれば、大学院生になれます。

b) M enyatakan suatu kebiasaan atau suatu hal yang berulang

(27) 隣の犬は主人を見れば、飛んでくる。

(28) 天気がよければ、ジョギングに行く。

Jika partikel ba digunakan dalam kalimat dalam kala lampau, maka kalimat tersebut menyatakan makna:

c) M enyatakan suatu kebiasaan yang pernah berlangsung.

(29) 学生時代は、冬になれば、スキーばかりしていた。

d) M enyatakan suatu 'pengetahuan' (ninshiki) yang bermakna kesadaran akan sesuatu

(30) よく見れば、彼女は美人ではなかった。

Partikel ba dapat digunakan dalam kalimat verbal, ajektival, dan kalimat nominal seperti yang nampak pada contoh berikut:

(31) その町は車で行けば三十分でいける。

(32) 安ければ買います

Partikel ba dapat digunakan dalam kalimat imperatif, kalimat permohonan, kalimat yang menyatakan saran, kalimat yang menyatakan ajakan atau kalimat yang menyatakan maksud. Tetapi, untuk kalimat dengan fungsi imperatif, permohonan, 
saran, ajakan atau kalimat yang menyatakan maksud klausa I tidak bisa berupa klausa berpredikat verba. Simak contoh berikut:

(33）明日天気がよければ、ドライブに行きましょう。

(34) 山本さんが来机ば知らせてください。

(35) シカゴへ行けばバスで行ったらどうですか。

Tetapi, diperbolehkan jika subjek dalam klausa I dan klausa II berbeda. Juga, diperbolehkan jika predikat dalam klausa I menjelaskan kondisi dari topik klausa. Perhatikan contoh berikut:

(36) 彼女が来机ば、すぐ出かけよう

(37) 部屋が暑ければ、空を開けてください。

Subjek pada kalimat yang menggunakan partikel ba diikuti oleh partikel ga. Partikel ba banyak digunakan dalam bahasa tulisan, dan berkesan formal.

3) Makna, Kategori Predikat, dan Modus Kalimat Tara

Partikel tara digunakan pada kalimat majemuk yang menyatakan persyaratan; seperti halnya partikel to dan partikel ba, tara juga dapat digunakan dalam kalimat dengan kala lampau dan kala non-lampau. Jika partikel tara digunakan dalam kala non-lampau, kalimat tersebut menyatakan makna:

a) M enunjukkan persyaratan yang bersifat 'pen gandaian'; tidak dapat dipastikan jika hal dalam klausa I terjadi akan menyebabkan timbulnya klausa II

Contoh:

(38) 100 万あったら、豪華船で世界一周したい。

(39) 雨がふったら、行きません。

b) Menunjukkan hubungan bahwa klausa I menjadi pemicu tindakan yang dinyatakan dalam klausa II

Contoh:

（40）ご飯を食べたら、私の部屋に来てください。

(41) 仕事が終わったら、プールー泳ぎに行こう。

jika digunakan dalam kalimat dengan kala lampau, menyatakan makna 'hal yang tidak direncanakan terjadi'; hal tersebut bersifat 'kebetulan' (guuzen), 'penemuan' (hakken), 'dipicu oleh sesuatu' (kikkake). Simak contoh berikut: 
（42）宝くじを買ったら、一等に当たった。

(43) 町を歩いていたら、前田先生を見かけた

(44) なかなか動かなかったが、このボタンを押したら、急に動き出した。

Partikel tara dapat digunakan dalam kal imat verbal, ajektival, juga nominal. D apat digunakan dalam kal imat tanya, juga dalam kalimat yang predikatnya menyatakan maksud dari pembicara (ajakan, keinginan, perintah, saran, dII). C ontoh:

(45) 私は大学を出たら小学校の先生になります。

(46) おもしろくなかったら読みませんよ。

(47)きらいだったら残してください。

(48) 英語だったら分かると思います。

(49) 雨が降ったら、試合は中止ですか。

(50) 仕事が早く終わったら僕のうちに来てください。

(51) 仕事が早く終わったら僕のうちに来たらどうですか。

Jika digunakan dalam kalimat dengan kala lampau, predikat dalam klausa II tidak bisa berupa predikat yang mencerminkan 'usaha' dari si pembicara. Simak contoh berikut:

(52) 学校へ行ったら、上田さんと話をした。

Partikel tara juga tidak lazim digunakan untuk menyatakan 'kondisi yang lazim terjadi' (ippan jouken) seperti berikut:

(53) 春が来たら、花が咲く。

Subjek pada kalimat yang menggunakan partikel tara diikuti oleh partikel ga. Partikel ini banyak dalam digunakan dalam bahasa lisan; dalam bahasa tulisan biasanya tidak digunakan partikel tara.

\section{KONJU NGSI KALAU DALAM BAHASA INDONESIA}

Pada bagian ini akan diuraikan mengenai makna, kategori predikat serta modus kalimat yang men gan dung konjun gsi kalau. Kata kalau dalam Kamus Besar Bahasa Indonesia memiliki arti sebagai berikut:

a) Kata penghubung untuk menandai syarat, sebagaimana nampak pada kalimat:

(54) Kalau keluar, harus minta izin dulu 
b) Seandainya; seperti nampak pada kalimat:

(55) Kalau ia tidak mau membayar utangnya, apa yang akan kau perbuat?

K alau digunakan jika syarat yang dimaksud bertalian den gan waktu. Kata kalau dalam bahasa Indonesia dikategorikan sebagai konjungsi; digunakan untuk menyatakan syarat terjadinya suatu peristiwa dalam klausa I jika peristiwa lain yang dinyatakan pada klausa II sudah terjadi. Tetapi, urutan induk kalimat dan anak kalimat dalam bahasa Indonesia dapat dipertukarkan, maka kalau dapat muncul di awal kalimat juga di tengah kalimat. Simak contoh berikut:

(56) Saya akan datang kalau diberi ongkos

(57) Kalau nenek pergi, kakek juga akan pergi

(58) Kami akan hadir kalau diberi undangan

Konjungsi kalau dapat bersubtitusi dengan konjungsi jika, bila, bilamana, apabila; dalam ragam non-formal kalau dapat disubtitusi dengan konjungsi asal. Simak contoh berikut:

(54a) Saya akan datang jika diberi ongkos

(54b) Jika diberi ongkos saya akan datang

(54c) Saya akan datang bila diberi ongkos

(54d) Bila diberi ongkos saya akan datang

(54e) Saya akan datang asal diberi ongkos

(54f) A sal diberi ongkos saya akan datang

K alau umum digunakan dalam kalimat ajektival, verbal, juga nominal. Simak contoh berikut:

(59)Segitiga ABC akan sama panjang dan sebangun dengan segitiga PQ R, kalau alasnya sama panjang.

(60)K alau aku menjadi bupati, kuan gkat kau jadi sekretarisku

(61)la menengok ke luar kalau-kalau anaknya sudah datang

(62)Kami amat khawatir, kalau-kalau persembunyiannya diketahui. 
Kalimat (59) merupakan kalimat ajektival, kalimat (60) dan (60) merupakan kalimat verbal, sedangkan kalimat (62) merupakan kalimat nominal. K alau juga dapat digunakan dalam kalimat deklaratif, interogatif, juga imperatif. Simak contoh berikut:

(63)N asib kita akan menjadi baik, kalau kita mau berusaha

(64)Kalau ia tidak mau membayar utangnya, apa yang akan kau perbuat?

(65)Baca buku itu! Kalau sudah selesai segera ke sini!

(66)Kalau boleh, nanti malam saya mau berangkat lagi ke Jakarta!

(67)Besok sore aku harus bertemu Tatang di Bekasi

(68)Sebaiknya diperhatikan umur saya kalau mau ada penentuan Manajer Personalia lagi

(69)Kalau tombol power ditekan, listrik akan mengalir

Kalimat (63) merupakan kalimat deklaratif, kalimat (55) merupakan kalimat interogatif, kalimat (64), (65), dan (66) merupakan kalimat imperatif, tetapi khusus pada kalimat (65) dan (66) imperatif mengandung makna permintaan/ permohonan.

Makna kalau dalam kalimat mencakup:

a) Aktifitas/ hal yangmuncul padaklausall terjadi segera setelah hal pada klausa I terjadi, contoh kalimat (64)

b) Menunjukkan suatu kondisi yang umum terjadi suatu konsekuensi yang umum terjadi, contoh kalimat (59)

c) M enunjukkan makna 'penemuan'; atas 'usaha' yang dilakukan pada klausa I, maka 'hasil' pada klausa II ditemukan, contoh kalimat (63)

d) M enunjukkan serangkaian aksi yang berhubungan dengan subjek yang menjadi topik pembicaraan, contoh kalimat (54), dan kalimat (66)

e) Menunjukkan hubungan persyaratan bahwa jika klausa I terjadi, maka secara otomatis klausa II akan terjadi, contoh kalimat (67) 
f) M enunjukkan makna persyaratan yang bersifat pen gandaian, seperti pada kalimat (60)

g) Menunjukkan hubungan bahwa klausa I menjadi pemicu tindakan yang dinyatakan dalam klausa II, seperti pada kalimat (64), (57), (58), dan (67)

TABH 1MANATQ, BA DANTARA

\begin{tabular}{|c|c|c|}
\hline PARाাKB & MANF & Kat \\
\hline \multirow[t]{7}{*}{$\pi$} & 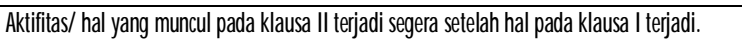 & M! \\
\hline & 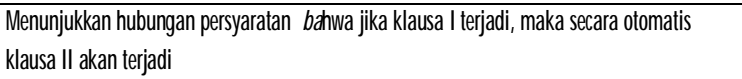 & ML \\
\hline & 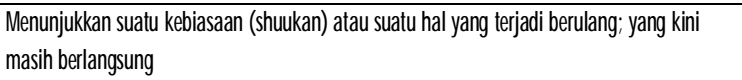 & $\mathrm{ME}$ \\
\hline & 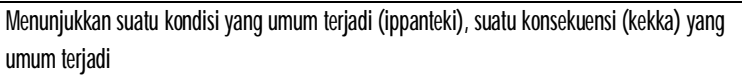 & MA \\
\hline & 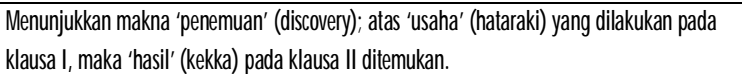 & МБ \\
\hline & 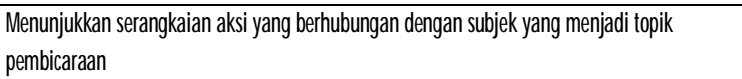 & ME \\
\hline & 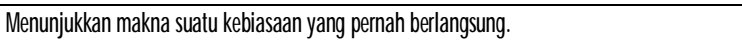 & MU \\
\hline \multirow[t]{4}{*}{$\mathrm{B}^{4}$} & 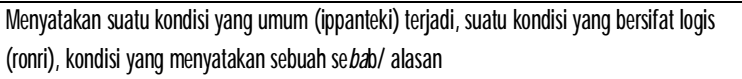 & ME \\
\hline & 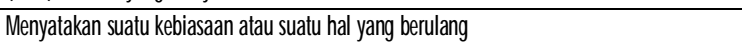 & $\overline{M E}$ \\
\hline & 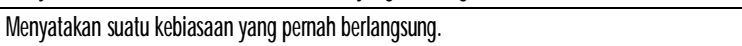 & MV \\
\hline & 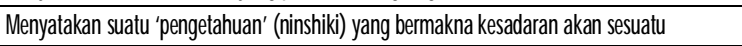 & $\mathrm{M} 1$ \\
\hline \multirow[t]{3}{*}{ TABA } & 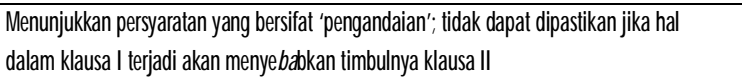 & $\mathrm{Ml1}$ \\
\hline & 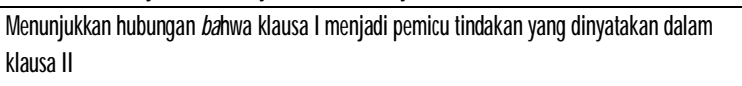 & $\mathrm{M} 2$ \\
\hline & 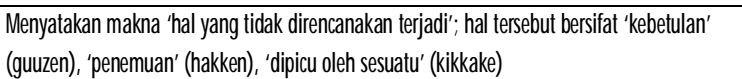 & $\mathbb{M}=$ \\
\hline
\end{tabular}

\section{DESKRIPSI KATEGORI MAKNA, KATEGORI}

PREDIKAT, DAN KATEG ORI MODUSTO, BA, TARA

DAN KALAU

Berdasarkan contoh di atas, dari segi makna, predikat pembentuk kalimat, dan modus kalimat, to, ba, tara serta kalau bisa dikategorikan sebagai berikut:

a. Kategori Makna

Partikel to memiliki tujuh kategori makna. Partikel ba memiliki 
empat kategori makna, dimana pada partikel ba dijumpai satu makna yang sama dengan makna partikel to; yaitu makna 'M enunjukkan makna suatu kebiasaan yang pernah berlangsung. Sedangkan partikel tara memiliki tiga kategori makna, dimana diantara ketiga makna tersebut tidak menunjukkan kemiripan makna dengan to maupun ba. Simak tabel 1.

Sedangkan konjungsi kalau, memiliki tujuh kategori makna, sebagaimana yang tampak pada tabel 2 di bawah ini.

TPBH 2 KATEGOR MANAKALAU

\begin{tabular}{|c|c|c|}
\hline KOYUNG & MAKA & KQE \\
\hline \multirow[t]{7}{*}{ KAA } & 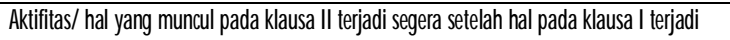 & $\mathrm{M}$ \\
\hline & 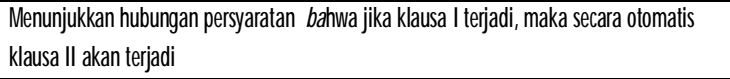 & ME \\
\hline & Menujukansatukonds yergumemtejad sutukan keri yengumemtejad & MA \\
\hline & 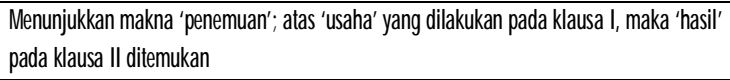 & $\mathrm{ME}$ \\
\hline & 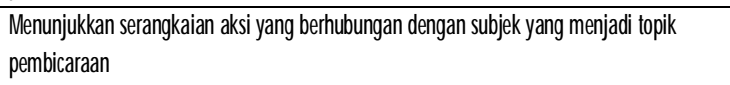 & $\mathrm{ME}$ \\
\hline & Merujuktanntkrapesyadanyengbesiftpergandia & M1 \\
\hline & 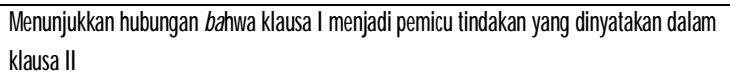 & M2 \\
\hline
\end{tabular}

TAEPH 3KATECOR PPEDKATTQ, BA TARA

\begin{tabular}{|c|c|c|}
\hline PARाাK & Pस⿴囗KA & KOE \\
\hline \multirow[t]{3}{*}{70} & Velbd & $\mathrm{Pl}$ \\
\hline & Adtivd & P2 \\
\hline & Nonind & $\mathrm{PB}$ \\
\hline \multirow[t]{3}{*}{ BA } & Verbd & $\mathrm{Pl}$ \\
\hline & Adtivd & $\mathrm{P} 2$ \\
\hline & Nonind & $\mathrm{PB}$ \\
\hline \multirow[t]{3}{*}{ TARA } & Vébal & PI \\
\hline & Adtivd & $\mathrm{P} 2$ \\
\hline & Nonind & $\mathrm{PB}$ \\
\hline
\end{tabular}

b. Kategori Predikat

Baik partikel to, ba, maupun tara memiliki tiga kategori predikat. Kalimat yang menggunakan partikel to, ba, maupun tara dapat berupa kal imat verbal (predikat berupa verba), kalimat ajektival (predikat berupa ajektif), atau kalimat nominal (predikat 
berupa nomina). K alau pun memiliki kategori predikat yang sama, yaitu verba, ajektif, dan nominal. Simak tabel 3 dan Tabel 4.

TAEH 4KAIECOR PREDIKATKALAU

\begin{tabular}{|c|c|c|}
\hline Kojings & Peedkd & Kode \\
\hline \multirow[t]{3}{*}{ KAAU } & Vethed & $\mathrm{Pl}$ \\
\hline & fjettivat & $P_{2}$ \\
\hline & Nonind & $\mathrm{PE}$ \\
\hline
\end{tabular}

c. Kategori Modus

Partikel to memiliki satu kategori modus, yaitu deklaratif. Partikel ba memiliki lima kategori modus, sedangkan partikel tara memiliki enam kategori modus. Dijumpai modus yang sama antara partikel to, ba, dan tara; yaitu modus deklaratif. Sedangkan untuk Selain itu, dijumpai pula kemiripan moduskalimat antara partikel ba dan tara, yaitu modus yang menyatakan ajakan, deklaratif, imperatif, dan saran. Sedangkan kalau hanya memiliki empat modus saja, yaitu deklaratif, interogatif, imperatif, dan permohonan. Simak tabel-tabel berikut.

TABH 5 KAIECOR MOOSTQ, BA TARA

\begin{tabular}{|c|c|c|}
\hline PARा1KB & MOOF & Kal \\
\hline $\bar{\pi}$ & [Aladif & $\mathrm{F}_{2}$ \\
\hline \multirow[t]{5}{*}{$B A$} & [elladif & $F_{2}$ \\
\hline & Inpedif & $\mathrm{E}$ \\
\hline & Pemderan & $F 6$ \\
\hline & Saan & Fi \\
\hline & fjakan & $\mathrm{F}]$ \\
\hline \multirow[t]{6}{*}{ TABt } & fidkr & $\mathrm{F}]$ \\
\hline & DAtadif & $\mathrm{F} 2$ \\
\hline & Qtatif & Б \\
\hline & Inpedif & $\mathrm{B} 3$ \\
\hline & Sad & Fl \\
\hline & Inteogdif & $F$ \\
\hline
\end{tabular}

TAEH 6KAIECOR MOOSKALA

\begin{tabular}{|l|l|l|}
\hline KONUNG & MOOS & KE \\
\hline \multirow{4}{*}{ KAA } & [edadif & FL \\
\cline { 2 - 3 } & Interogdif & FL \\
\cline { 2 - 3 } & Impeadif & F \\
\cline { 2 - 3 } & Fendona & FE \\
\hline
\end{tabular}




\section{PER SAMAAN DAN PERBEDAAN TO, BA, TARA DAN}

KALAU

Berikut akan diuraikan persamaan dan perbedaan to, ba, tara dalam bahasa Jepang dengan kalau dalam bahasa Indonesia

a. Perbandingan To dengan Kalau

M 1, M 2, M 4, M 5, dan M 6 merupakan makna yang ada dan berpadanan (icchi) dalam bahasa Indonesia dan bahasa Jepang. Sedangkan M 3 dan M 7 tidak ada dalam kalimat yang menggunakan konjugasi kalau, tetapi dijumpai pada kalimat bahasa Jepang yang menggunakan partikel to. $\mathrm{H}$ al ini menunjukkan fenomena shinki, seperti yang tampak pada tabel 7 berikut.

TAEH 7PEBANDNGANKAIECOR MANATODANGANKALAU

\begin{tabular}{|c|c|c|c|}
\hline MANK & KOEMAKN & $\pi$ & KAA \\
\hline 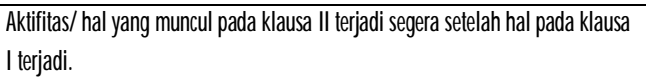 & $\mathrm{M}$ & $\bullet$ & $\bullet$ \\
\hline 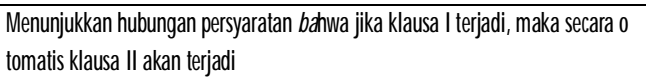 & ME & $\bullet$ & $\bullet$ \\
\hline 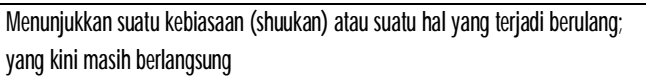 & $\mathrm{ME}$ & $\bullet$ & $\mathrm{x}$ \\
\hline $\begin{array}{l}\text { Merujuktanstukonds yergumemtejad (ippartdi), stukosekens } \\
\text { (kdka) yergummtejad }\end{array}$ & MA & $\bullet$ & $\bullet$ \\
\hline 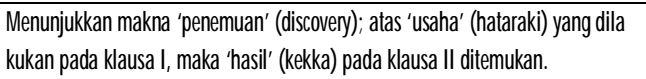 & MD & $\bullet$ & $\bullet$ \\
\hline 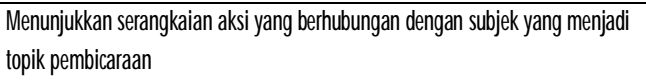 & ME & $\bullet$ & $\bullet$ \\
\hline Merujukannakrastukediaranyergperahbelargang & MV & $\bullet$ & $\mathrm{x}$ \\
\hline
\end{tabular}

TABH 8PEBANDNGANKAIECOR PPHOKKAT TODANGANKALAU

\begin{tabular}{|c|c|c|c|}
\hline 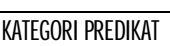 & 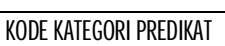 & $\mathrm{TO}$ & KAAU \\
\hline Valbal & $\mathrm{PI}$ & $\bullet$ & $\bullet$ \\
\hline Nonind & $\mathrm{P} 2$ & $\bullet$ & $\bullet$ \\
\hline Addiva & PB & $\bullet$ & $\bullet$ \\
\hline
\end{tabular}

Perbandingan antara to dengan kalau dari segi kategori predikat pembentuk kalimat dapat dilihat pada tabel 8. Dari segi predikat dalam kalimat, bahasa Jepang dan bahasa Indonesia menunjukkan kesamaan (icchi); dimana kaetgori predikat berupa verba, nomina, maupun ajektiva sama-sama ditemukan 
baik pada bahasa Jepang (to) maupun bahasa Indonesia (kalau).

Perbandingan antara to dengan kalau dari segi kategori modus kal imat dapat dilihat pada tabel 9. F2 terdapat dalam to maupun kalau (icchi). Tetapi F3, F4, dan F6 tidak dijumpai untuk kalimat yang men ggunakan partikel to (ketsujo).

TABH 9PEBANDNCANKAIECOR MOUSTOLENGANKALAU

\begin{tabular}{|l|l|l|l|}
\hline MOUF & KOEMOIF & T & KAA \\
\hline DAtadil & F & $\bullet$ & $\bullet$ \\
\hline Inteogdif & FA & X & $\bullet$ \\
\hline Impedif & F & X & $\bullet$ \\
\hline Pemehora & FE & X & $\bullet$ \\
\hline
\end{tabular}

b. Perbandingan $\mathrm{Ba}$ dengan $\mathrm{K}$ alau

Perbandingan kategori makna ba dengan kalau tidak menunjukkan fenomena makna yang sepadan. M akna M 7, M 8. $\mathrm{M}$, dan $\mathrm{M} 10$ hanya dijumpai pada kalimat yang mengandung ba, tapi tidak dijumpai pada kalimat yang mengandung kalau. Pada hal ini, ba dengan kalau menunjukkan fenomena ketsujo, seperti yang tampak pada tabel 10 .

TAEH 10PRBANDINGANMANABADENGANKALAU

\begin{tabular}{|c|c|c|c|}
\hline MANK & KQEMANK & $B A$ & KAAU \\
\hline Merujukennakrasatukejasanyengperahbelargang & MV & $\bullet$ & $\mathrm{x}$ \\
\hline 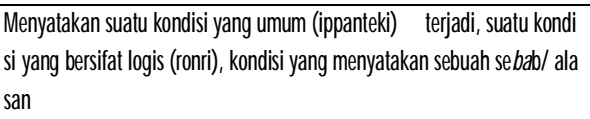 & ME & $\bullet$ & $\mathrm{x}$ \\
\hline 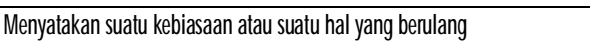 & ME & $\bullet$ & $\mathrm{X}$ \\
\hline 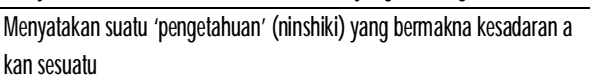 & $\mathrm{MO}$ & $\bullet$ & $\mathrm{x}$ \\
\hline
\end{tabular}

Dari segi predikat dalam kalimat, antara ba dengan kalau menunjukkan kesamaan (icchi). Simak tabel 11 di bawah ini.

TABH 11 PEBANDNGANKAIECOR PPHDIKATBADENGANKALAU

\begin{tabular}{|c|c|c|c|}
\hline KAE्G P FसDA & 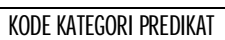 & $\pi$ & KAA \\
\hline Veibd & $\mathrm{P}]$ & $\bullet$ & $\bullet$ \\
\hline Nanina & $\mathrm{P}_{2}$ & $\bullet$ & $\bullet$ \\
\hline Adeltiva & $P$ & $\bullet$ & $\bullet$ \\
\hline
\end{tabular}


Sedangkan dari segi modus kalimat, ba dan kalau menunjukkan fenomena icchi, shinki, dan ketsujo. F2, F3, dan F6 dijumpai dalam kalimat yang mengandung ba maupun kalau (shinki).. F1 dan F7 tidak dijumpai dalam kalau, tetapi dijumpai dalam ba (shinki). F4 dijumpai dalam kalau, tapi tidak dijumpai dalam ba (ketsujo) . Simak tabel 12 berikut.

TAEH12PEBANDNGANKAIECOR MOUSBADANGANKALAU

\begin{tabular}{|c|c|c|c|}
\hline MOS & KAEMDS & BA & KALA \\
\hline Ajakan & $\mathrm{Fl}$ & $\bullet$ & $x$ \\
\hline Dekadif & $\mathrm{F} 2$ & $\bullet$ & $\bullet$ \\
\hline Impedif & F3 & $\bullet$ & $\bullet$ \\
\hline Interogdif & F4 & $x$ & $\bullet$ \\
\hline Pendoran & F6 & $\bullet$ & $\bullet$ \\
\hline Saran & $\mathrm{F} 7$ & $\bullet$ & $x$ \\
\hline
\end{tabular}

TABH 13PEBANDINGANKAEECOR MANATABADENGANKALAU

\begin{tabular}{|c|c|c|c|}
\hline MANK & KGEMANF & TABt & KAA \\
\hline 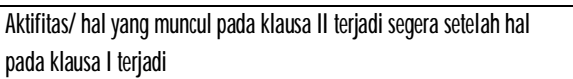 & M & $\mathrm{X}$ & $\bullet$ \\
\hline 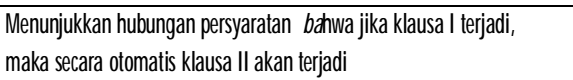 & ME & $\mathrm{X}$ & $\bullet$ \\
\hline $\begin{array}{l}\text { Menujukansatukonds yergunamtejad stukosetueri } \\
\text { yergumemtejad }\end{array}$ & $\mathrm{NA}$ & $\mathrm{X}$ & $\bullet$ \\
\hline 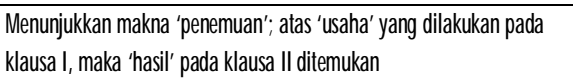 & MD & $\mathrm{X}$ & $\bullet$ \\
\hline 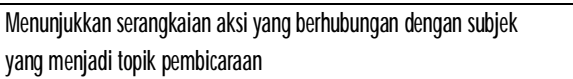 & M6 & $\mathrm{x}$ & $\bullet$ \\
\hline Merujukanndkapessedtanyengbesiftpergandia & M1 & $\bullet$ & $\bullet$ \\
\hline 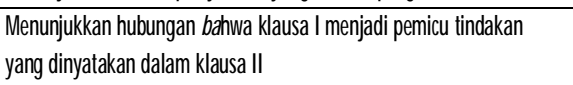 & $\mathrm{M} 2$ & $\bullet$ & $\bullet$ \\
\hline 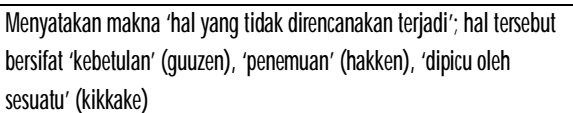 & $\mathrm{M} \Sigma$ & $\bullet$ & $\mathrm{x}$ \\
\hline
\end{tabular}

C. Perbandingan Tara dengan $\mathrm{K}$ alau

Dari data kalimat yang diperoleh, ditemukan bahwa makna tara dan kalau menunjukkan fenomena icchi untuk M 11 dan M 12, fen omena ketsujo untuk M 1, M 2, M 4, M 5, dan M 6. Selain itu dijumpai pula fenomena shinki untuk M 13. Simak tabel 13.

Dari segi predikat kalimat, tara dan kalau menunjukkan 
fenomena shinki, dimana unsur predikat verbal, nominal, maupun ajektival dapat digunakan untuk membuat kalimat berpartikel tara maupun berkonjungasi kalau. Simak tabel 14 berikut.

TABH 14PEBANDNGANKAIEGOR PPEDIKAT TARADENGANKALAU

\begin{tabular}{|c|c|c|c|}
\hline KAEEGR सEDKA & KOEKAEEGA PRD||KAT & TABA & KAAU \\
\hline Velat & P] & - & - \\
\hline Neniral & $\mathrm{P} 2$ & - & - \\
\hline Ádtivat & PB & - & - \\
\hline
\end{tabular}

Sedangkan dari segi modus kalimat, tara dan kalau menunjukkan fenomena icchi, shinki, dan ketsujo. F2, F3, dan F4 dijumpai dalam bahasa Indonesia dan Jepang (icchi). F6 dijumpai dalam bahasa Indonesia, tetapi tidak dijumpai delam bahasa Jepang (ketsujo). F1, F5, dan F7 dijumpai dalam bahasa Jepang tetapi tidak dijumpai dalam bahasa Indonesia (shinki). Simak tabel 15 di bawah ini.

TAER 15PEBANDNGANKAIECOR MOUSTARADENGANKALAU

\begin{tabular}{|c|c|c|c|}
\hline MOOF & KAEMOOF & TABA & KAAU \\
\hline Ázar & $\mathrm{F}]$ & $\bullet$ & $x$ \\
\hline LAKadif & $F_{2}$ & $\bullet$ & $\bullet$ \\
\hline Inpedif & $\mathrm{E}$ & $\bullet$ & $\bullet$ \\
\hline Intewadif & FL & $\bullet$ & $\bullet$ \\
\hline Qtatif & ⿷ & $\bullet$ & $x$ \\
\hline Perndhoran & 16 & $x$ & $\bullet$ \\
\hline Sarn & $\mathrm{F} 7$ & $\bullet$ & $x$ \\
\hline
\end{tabular}

\section{SIMPULAN}

Kalau dalam Bahasa Indonesia termasuk dalam kelas kata konjungsi, sedangkan to,ba, tara dalam Bahasa Jepang termasuk dalam kelas kata partikel. Walaupun begitu, kalau, to, ba, dan tara memiliki fungsi yang sama dalam kalimat, yaitu untuk menyatakan hubungan persyaratan dalam kalimat luas bertingkat.

Berdasarkan hasil analisis data kalimat, diketahui bahwa jumlah kategori makna to, ba, tara lebih banyak dibandingkan 
dengan jumlah kategori makna kalau. Maka secara umum, to, ba, tara bisa diterjemahkan langsung menjadi kalau dalam bahasa Indonesia. $\mathrm{Hal}$ ini menunjukkan fenomena konvergen dalam pemadanan kalimat yang menggunakan to, ba, tara ke dalam bahasa Indonesia. Sebaliknya, kalau dalam bahasa Indonesia menjadi divergen ketika diterjemahkan ke dalam bahasa Jepang. Untuk memilih padanan yang tepat, hal yang perlu diperhatikan adalah makna serta modus kalimat dari bahasa sumber dan bahasa sasaran; khususnya makna serta modus yang menunjukkan gejala shinki dan ketsujo. M akna kalimat bersyarat to, ba, tara yang tidak dijumpai dalam kalau adalah makna-makna berikut:

1. M enunjukkan suatu kebiasaan (shuukan) atau suatu hal yang terjadi berulang; yang kini masih berlangsung

2. Menunjukkan makna suatu kebiasaan yang pernah berlangsung.

3. Menyatakan suatu kondisi yang umum (ippanteki) terjadi, suatu kondisi yang bersifat logis (ronri), kondisi yang menyatakan sebuah sebab/ alasan

4. M enyatakan suatu kebiasaan atau suatu hal yang berulang

5. M enyatakan suatu 'pengetahuan' (ninshiki) yang bermakna kesadaran akan sesuatu

6. M enyatakan makna 'hal yang tidak direncanakan terjadi'; hal tersebut bersifat 'kebetulan' (guuzen), 'penemuan' (hakken), 'dipicu oleh sesuatu' (kikkake)

Karena ada perbedaan dari jumlah kategori makna tersebut, meskipun secara umum kalimat luas bertingkat yan g men yatakan syarat dengan partikel to, ba, tara dalam bahasa Jepang bisa diterjemahkan langsung ke dalam bahasa Indonesia dengan menggunakan kalau, nuansa makna yang spesifik menjadi tidak tampak, terutama untuk kategori makna dari to, ba, tara yang tidak dijumpai dalam makna kalau.

Dari segi predikat dalam kalimat, baik to, ba, tara maupun kalau menunjukkan karakteristik yang berpadanan. Tetapi, khusus untuk partikel ba, saat modus menyatakan imperatif, permohonan, saran, ajakan atau kalimat yang menyatakan 
maksud predikat tidak bisa berupa verba; kecuali jika subjek dalam klausa I dan klausa II berbeda. Juga, diperbolehkan jika predikat dalam klausa I menjelaskan kondisi dari topik klausa.

Dari segi modus, modus kalimat yang tidak dijumpai dalam kalau adalah modus-modus berikut:

1. Modus ajakan

2. M odus saran

3. Modus optatif

D engan kata lain, umumnya kalimat kalimat luas bertingkat yang menyatakan syarat dengan konjungsi kalau dalam Bahasa Indonesia tidak digunakan untuk menyatakan kalimat ajakan, kalimat saran, dan kalimat optatif (harapan/ keinginan).

DAFTAR SINGKATAN

M NTK I : M inna no N ihongo Terjemahan dan Keterangan Tata Bahasa jilid I

MNTK II : Minna no N ihongo Terjemahan dan Keterangan Tata Bahasa jilid I

PPBJ : Partikel Penting Bahasa Jepang

\section{DAFTAR PUSTAKA}

Chaer, Abdul. (2009). Sintaksis Bahasa Indonesia (Pendekatan Proses). Jakarta: Rineka Cipta

Chino Naoko. (2004). Partikel Penting Bahasa Jepang. Bekasi: Kesaint Blanc

Fahmi, Zulkarnain. (2006). Analisis Kesalahan Penggunaan Kalimat Bersyarat ba tara nara to Pada M ahasiswa Prodi Pendidikan Bahasa Jepang Fakultas Pendidikan Bahasa dan Seni Universitas Pendidikan Indonesia (Tesis pada Sekolah Pascasarjana Universitas Pendidikan Indonesia). Tidak dipublikasikan

Ichikawa Yasuko. (2005). Shokyuu Nihongo Bunpo to Oshiekata no Pointo. Tokyo: 3A Network

Iori Isao, Takanishi Shino, Nakanishi Kumiko, dan Yamada Toshihiro. (2000). Shokyu o Oshieru Hito no Tame no Nihongo Bunpo Handobukku. Tokyo: 3A Corporation

Machali, Rochayah. (2009). Pedoman Bagi Penerjemah. Bandung: Kaifa

Makino, Seiichi dan Tsutsui Michio. (1988). A Dictionary of Basic Japanese Grammar. Tokyo: The Japan Times

Nurhadi. (1995). Tata Bahasa Pendidikan. Semarang: IKIP Semarang Press

Putrayasa, Ida Bagus. (2009). Tata Kalimat Bahasa Indonesia. Bandung: Refika Aditama

Putrayasa, Ida Bagus. (2009). Jenis Kalimat dalam Bahasa Indonesia. Bandung: Refika Aditama

Rahardi, Kunjana. (2009). Pragmatik Kesantunan Imperatif Bahasa Indonesia. Jakarta: Erlangga

Sutedi, Dedi. (2009). Penelitian Pendidikan Bahasa Jepang. Bandung: Humaniora 
JOURNAL OF

JAPANESE LANGUAGE

EDUCATION \&

LINGUISTICS

(2000). Minna no Nihongo Shokyu I Honyakuû0Bunpou Kaisetsu Indoneshiagohan. Tokyo: 3A Corporation

(2001). Minna no Nihongo Shokyu II Honyakuû0Bunpou Kaisetsu Indoneshiagohan. Tokyo: 3A Corporation 